\title{
Individual growth in Jack mackerel (Trachurus murphyi) of the Southeastern Pacific Ocean using sagitta otolith weight, daily rings, and annual rings
}

\section{Crecimiento individual en jurel (Trachurus murphyi) del Océano Pacífico Suroriental utilizando el peso del otolito sagittae, anillos diarios y anillos anuales}

\section{Hugo Arancibia ${ }^{1}$, Lilian Cisterna ${ }^{2,3, *}$ \& Aquiles Sepúlveda ${ }^{3}$}

\author{
${ }^{1}$ Asesorías Ocean Technology and Aquaculture Chile Ltda., Las Violetas 1858-16, San Pedro de La Paz, Concepción, Chile. \\ 2Programa de Doctorado en Ciencias con mención en Manejo de Recursos Acuáticos Renovables (MaReA), Departamento de Oceanografía, Facultad de Ciencias Naturales y \\ Oceanográficas, Universidad de Concepción, P.O. Box 160-C, Concepción, Chile. \\ ${ }^{3}$ Departamento de Pesquerías, Instituto de Investigación Pesquera, Av. Cristóbal Colón 2780, Talcahuano, Chile. \\ *E-mail: Icisterna@inpesca.cl
}

\begin{abstract}
We estimated the growth of Jack mackerel (Trachurus murphyi) using increments of daily growth, otolith weight and annual ring reading in sagittal otoliths. The daily micro-increments were used to fit ring density to the otolith radius $(n=4481)$ and then to estimate the age of the individual in days. The parameters of the von Bertalannfy growth equation were: maximum theoretical fork length, $\mathrm{FL}_{\infty}=75 \mathrm{~cm}$; individual growth coefficient, $\mathrm{K}=0.16$ year $^{-1}$; theoretical age at which fish length is zero, $\mathrm{t}_{0}=-0.19$ years. The growth parameters of $T$. murphyi estimated using annual rings reading were: $\mathrm{K}=0.10$ year ${ }^{-1}, \mathrm{FL}_{\infty}=74.7 \mathrm{~cm}$, $\mathrm{t}_{0}=-0.50$ years. The growth parameters estimated using otolith weight were: $\mathrm{K}=0.15$ year $^{-1}, \mathrm{FL}_{\infty}=75.0$ $\mathrm{cm}, \mathrm{t}_{0}=-0.48$ years. The parameter $\mathrm{K}$ estimated with the daily micro-increments was similar to the $\mathrm{K}$ estimated using sagittal otolith weights. We constructed a size-age key for T. murphyi using otolith weight, OW (milligrams) as a variable was: $\mathrm{OW}=0.0323^{*} \mathrm{t}-15.197\left(\mathrm{r}^{2}=0.68\right)$. We recommend using otolith weight to estimate age in T. murphyi due to this technique is statistically reliable, but also cheap and fast.
\end{abstract}

Keywords: estimator of the age, growth parameters, otolith weight, Trachurus, $t$ (years).

\section{RESUMEN}

Se estimó el crecimiento del jurel (Trachurus murphyi) usando incrementos de crecimiento diario, peso de otolito y lectura de anillos anuales en otolitos sagitales. Los micro incrementos diarios se utilizaron para ajustar la densidad del anillo al radio del otolito $(n=4481)$ y luego para estimar la edad del individuo en días. Los parámetros de la ecuación de crecimiento de von Bertalannfy fueron: longitud máxima teórica a la horquilla, $\mathrm{FL}_{\infty}=75 \mathrm{~cm}$; coeficiente de crecimiento individual, $\mathrm{K}=0,16$ año-1; edad teórica a la que la talla de los peces es cero, $t_{0}=-0,19$ años. Los parámetros de crecimiento de $T$. murphyi estimados usando la lectura de anillos anuales fueron: $\mathrm{K}=0,10$ año $^{-1}, \mathrm{FL}_{\infty}=74,7 \mathrm{~cm}, \mathrm{t}_{0}=-0,50$ años. Los parámetros de crecimiento estimados usando el peso del otolito fueron: $\mathrm{K}=0,15 \mathrm{anno}^{-1}, \mathrm{FL}_{\infty}=75,0 \mathrm{~cm}, \mathrm{t}_{0}=-0,48$ años. El parámetro $\mathrm{K}$ estimado con los microincrementos diarios fue similar al $\mathrm{K}$ estimado usando pesos de otolitos sagitales. Se construyó una clave de tamaño-edad para T. murphyi usando el peso del otolito, OW (miligramos) como una variable fue: $\mathrm{OW}=0,0323^{*} t-15,197\left(r^{2}=0,68\right)$. Se recomienda usar el peso del otolito para estimar la edad en T. murphyi, debido a que esta técnica es estadísticamente confiable, pero también barata y rápida.

Palabras clave: estimador de la edad, parámetros de crecimiento, peso de otolitos, Trachurus,t (años). 


\section{INTRODUCTION}

The Jack mackerel (Trachurus murphyi Nichols, 1920) is the main fish resource species of the nearshore fleets of Chile and Peru that operate in the Southeastern Pacific Ocean, in their respective economic exclusion zones (EEZ), as well as the international dragging fleets of China, Russia, Taiwan and others that operate outside the EEZ. The maximum official total landings in Chile occurred in 1995, with 4.96 million tons. By comparison, the total capture of T. murphyi in 2017 by all national and international fleets, according with the South Pacific Regional Fisheries Management Organization (SPRFMO 2017), was 303,555 tons, but it increased to 782,000 tons for 2021, corresponding 504,800 tons to the Chilean fleet. The annual quotas of T. murphyi are proposed by the Scientific Committee of the SPRFMO and approved by the officials representing the participating countries, usually fishing ministers or vice ministers, or representatives of the Ministries of Foreign Affairs.

Age-structured evaluations are used to estimate the stock of $T$. murphyi, which means that the total capture weight must be transformed into age-specific capture numbers, which is done using age-size keys and the individual growth parameters $\mathrm{K}$ (year $\left.{ }^{-1}\right), \mathrm{FL}_{\infty}(\mathrm{cm})$ and $\mathrm{t}_{0}$ (years). The methods used to estimate individual ages of T. murphyi have been annual growth ring counts (Pavez \& Saa 1978; Aguayo et al.
1981; Kochkin 1998) and analysis of modal size progression (Cubillos \& Grechina 1998) (Fig. 1). However, estimation of individual age in species of the genus Trachurus is complex, since the annual growth increments in the sagittal otoliths are very difficult to interpret (Kochkin 1998; Araya et al. 2001; Stewart \& Ferrel 2001; Waldrom \& Kerstan 2001; Vasconcelos et al. 2006), mainly due to the deposition of aragonite, which increases otolith thickness (Green et al. 2009).

Pannella (1974) identified micro-rings in sagittal otoliths in fish species of temperate zones of the northwest Atlantic Ocean, including silver hake (Merluccius bilinearis), red hake (Urophycis chuss), cod (Gadus morhua) and winter flounder (Pseudopleuronectes americanus), and assumed that these micro-rings were formed daily. Almost 20 years later, Araya et al. (2003) showed experimentally that T. murphyi produces daily micro-increments of growth in sagittal otoliths. Later, Cisterna \& Arancibia (2017) reported that the minimal width of each micro-increment in adult T. murphyi is $1.84 \mu \mathrm{m}$.

Measuring micro-increments is slow and expensive, thus it is not used massively to determine individual age in fish. An alternative method to estimate fish age, which is rapid and economic, is measuring otolith weight (Pino et al. 2004; Lou et al. 2005; Pilling et al. 2003; Bermejo 2014; Hanson \& Stafford 2017), since this increases with the growth in length of the fish. Araya et al. (2001) used modal frequency decomposition analysis of sagitta otolith weight to show that there is a

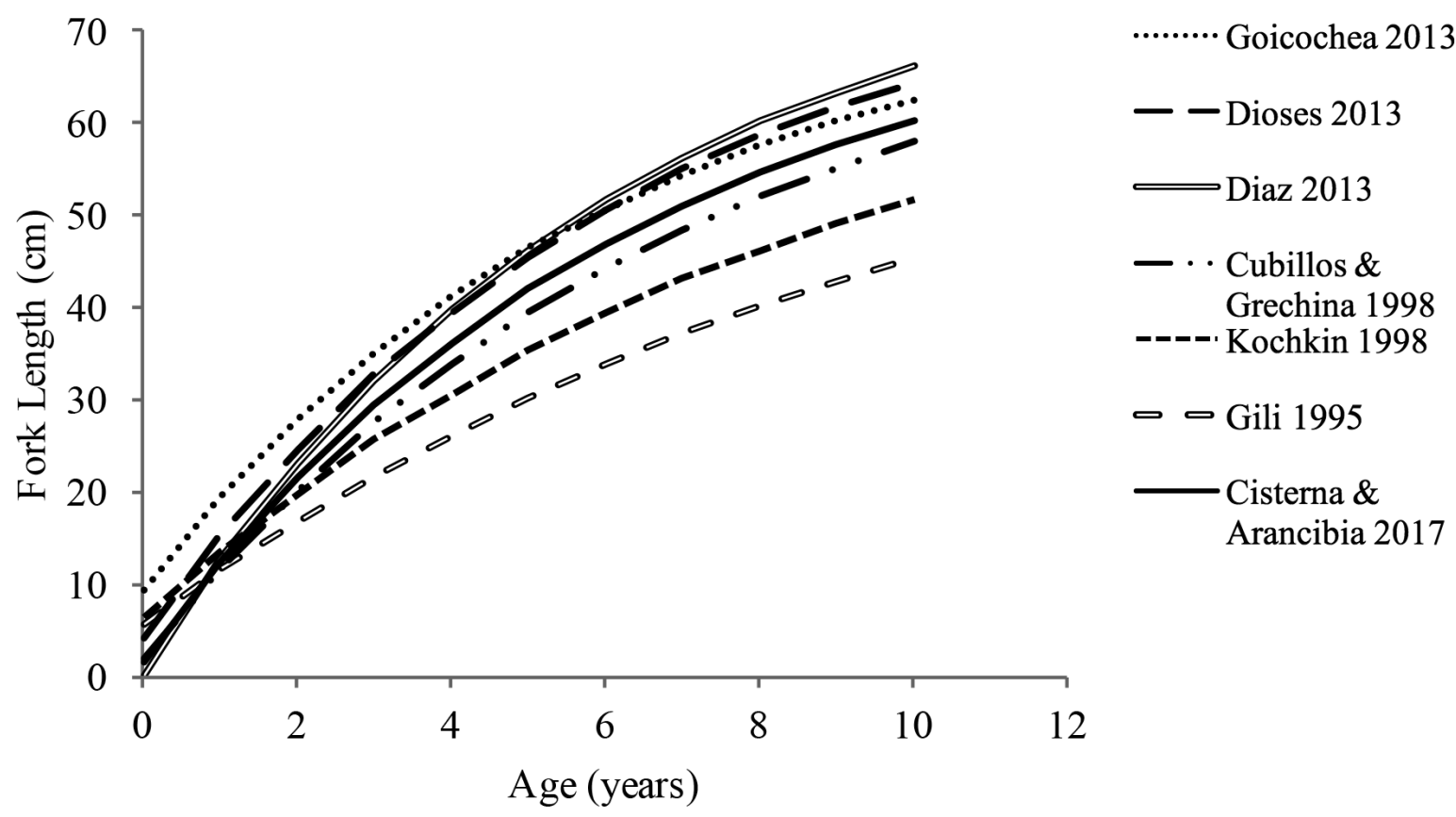

Figure 1. Comparison of von Bertalanffy growth curves for Trachurus murphyi (different authors and this study). / Comparación de las curvas de crecimiento de von Bertalanffy para Trachurus murphyi (diferentes autores y este estudio). 
significant relation between these weights and age. These authors also estimated the average annual weight increase to be $8.256 \mathrm{mg} \mathrm{year}^{-1}$.

The objective of this study is to estimate individual growth parameters of $T$. murphyi using three methods in parallel: annual growth rings, daily increments and otolith weight.

\section{MATERIAL AND METHODS}

\section{Preparation of thin sections}

We used thin sections $(0.5 \mathrm{~mm})$ of sagittal otoliths to measure daily growth increments of $T$. murphyi, using the technique of Green et al. (2009), which was applied by Cisterna \& Arancibia (2017) to this species.

\section{MeAsuRement OF THIN SECTIONS OF OTOLITHS}

The otolith micro-increments were observed in an optical microscope as alternately clear and dark concentric rings. According to Green et al. (2009), each pair of rings constitutes a daily increment in growth. The procedure for reading these increments is described in Cisterna \& Arancibia (2017). We used $400 \mathrm{X}$ and $1000 \mathrm{X}$ magnification to count the microincrements. Counts were performed following a radius of the otolith; their structural characteristics (discontinuities and wider increments) were used as markers to facilitate counting.

\section{NUMERICAL INTEGRATION OF DAILY INCREMENTS}

The otolith microstructure of adult individuals of T. murphyi included areas with clear-cut and easily visible microincrements and other diffuse areas, which did not allow all daily rings to be counted in some individuals. Thus, to estimate the total number of micro-increments of each otolith we used the numerical integration method proposed by Ralston and Williams (1989) and applied to T. murphyi by Araya et al. (2001). Otolith growth was calculated using the following expression:

$$
\frac{\Delta x}{\Delta \text { increments }}=\frac{\Delta x}{\Delta t} \approx \frac{d x}{d t}
$$

where: $d x$ is the length of the segment $(\mu \mathrm{m})$ at a distance $x$ from the nucleus; $d t$ is the time (days), which is the number of daily increments.

Then $d t$ is treated as a definite integral limited by the nucleus $(x=0)$ and the radius of the otolith, in order to estimate the number of micro-increments in otolith sections where it is not possible to see all the micro-rings. According to Araya et al. (2001), the analytic expression to estimate the age (in days) using the radius of the otolith is as follows:

$$
\frac{d x}{d t}=f(x)=a x(1-b c x)^{1 / c}
$$

where: $a=0.144571 ; b=0.021913 ; c=-0.751643 ; \mathrm{n}=5.787$; $r^{2}=0.53$

The numerical integral defined by Equation 2 was evaluated using the Numerical Integration tool, obtained from Numerical Analysis and Applications (www.hvks.com). The age in days estimated for each fish was transformed to years by dividing the number of micro-increments by 365 .

The parameters $\mathrm{FL}_{\infty}(\mathrm{cm}), \mathrm{K}$ (year ${ }^{-1}$ ) and $\mathrm{t}_{0}$ (years) were estimated using the TableCurve 2D software. Since it was not possible to sample individuals of T. murphyi with fork length greater than $64 \mathrm{~cm}$, we used $\mathrm{FL}_{\infty}=75 \mathrm{~cm}$, based on Kochkin (1998), who obtained this value of $\mathrm{FL}_{\infty}$ using annual rings in entire otoliths and longitudinal sections.

\section{Preparation For Otolith WeIGHING}

We assumed that the annual increase in otolith mass was $8.256 \mathrm{mg} \mathrm{year}^{-1}$, according to Araya et al. (2001). We used 187 (left) sagitta otoliths of individuals of T. murphyi to count micro-increments. We recorded the weight of 75 whole otoliths in an analytic balance (precision $0.0001 \mathrm{~g}$ ). Otoliths were first cleaned with distilled water and dried at constant temperature $\left(30^{\circ} \mathrm{C}\right)$ in a Binder model ED-53 oven for $24 \mathrm{~h}$.

\section{READING AND MEASUREMENT OF ANNUAL RINGS}

Otoliths were hydrated for $1 \mathrm{~h}$ to analyze annual growth rings. Observations were made with a Zeiss stereomicroscope model Stemi DV4 using 10X. The sample included 7,610 otoliths of fish collected from 2004 to 2011 off the coast of Chile (range of FL: 18 to $60 \mathrm{~cm}$ ). However, fish of age 1 were absent in the sample. To avoid bias in the estimation of the intercept of the linear regressions, we forced the regressions through the origin, meaning that $\mathrm{t}_{0}=0$.

\section{Comparison OF GROWTH CURVES}

We applied the test of coincident curves (Haddom 2001) to compare the growth curves (daily micro-increments, otolith weight and annual rings) of T. murphyi.

CONSTRUCTION OF A SIZE-AGE KEY USING WEIGHTS OF SAGITTA OTOLITHS To construct a size-age key we analyzed 1,300 otoliths of juvenile and adult T. murphyi (range: 19 to $64 \mathrm{~cm} \mathrm{FL}$ ) which were obtained randomly from Chilean industrial landings 
between 1998 and 2016. Each otolith was weighed in a Denver Instrumental analytical balance model AA (precision $0.0001 \mathrm{~g}$ ). Then the weight of each otolith was transformed to age in days using the following relation:

$$
\mathrm{AGE}=\frac{\mathrm{OW}}{8.256}
$$

where: OW is otolith weight in $\mathrm{mg}$; the constant 8.256 ( $m g \mathrm{yr}^{-1}$ ) is the annual growth rate of T. murphyi, according to Araya et al. (2003).

\section{RESULTS}

We found a high correlation between otolith weight and fork length for $T$. murphyi $\left(r^{2}=0.90\right)$, and a high correlation between otolith weight and fish age $\left(r^{2}=0.94\right)$ (Figs. 2 and 3$)$. The parameters of the von Bertalanffy equation estimated using daily increments, annual increments and otolith weight are shown in Table 1. The growth curves using daily growth increments and otolith weight are clearly superimposed (Fig. 4). There were significant differences between the curve obtained with annual rings and otolith weight (Table 2), and also between the annual ring and daily increment curves. The differences between the curves of otolith weight and daily increments were not significant (Table 2).

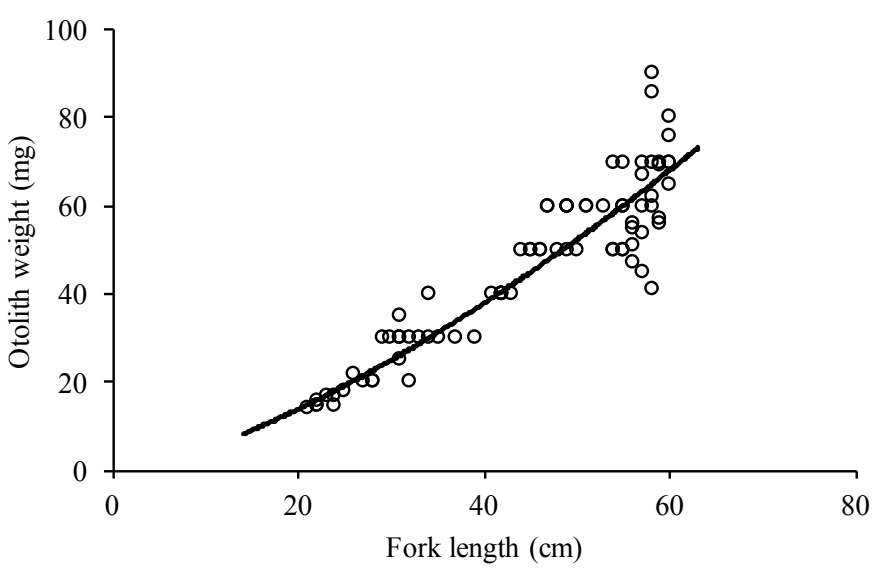

Figure 2. Otolith weight (mg) as a function of fork length $(\mathrm{cm})$ for Trachurus murphyi, OW = otolith weight $(\mathrm{mg}) ; \mathrm{FL}=$ fork length (cm); OW = 0.19 FL $1.4\left(r^{2}=0.90\right)$. / Peso del otolito (mg) en función de la longitud de la horquilla $(\mathrm{cm})$ para Trachurus murphyi, OW = peso del otolito $(\mathrm{mg}) ; \mathrm{FL}=$ longitud de la horquilla $(\mathrm{cm}) ; \mathrm{OW}=$ $0,19 \mathrm{FL}^{1,4}\left(\mathrm{r}^{2}=0,90\right)$.
The age-size key obtained using otolith weight is composed of individuals of age 1 to 11 years. The mode was at ages 2 and 3 years ( $45 \%$ of the sample; size range 23 to 39 $\mathrm{cm} \mathrm{FL})$, while the least represented age class was $9+(<2 \%$; size range: 50 to $64 \mathrm{~cm} \mathrm{FL)} \mathrm{(Table} \mathrm{3).}$

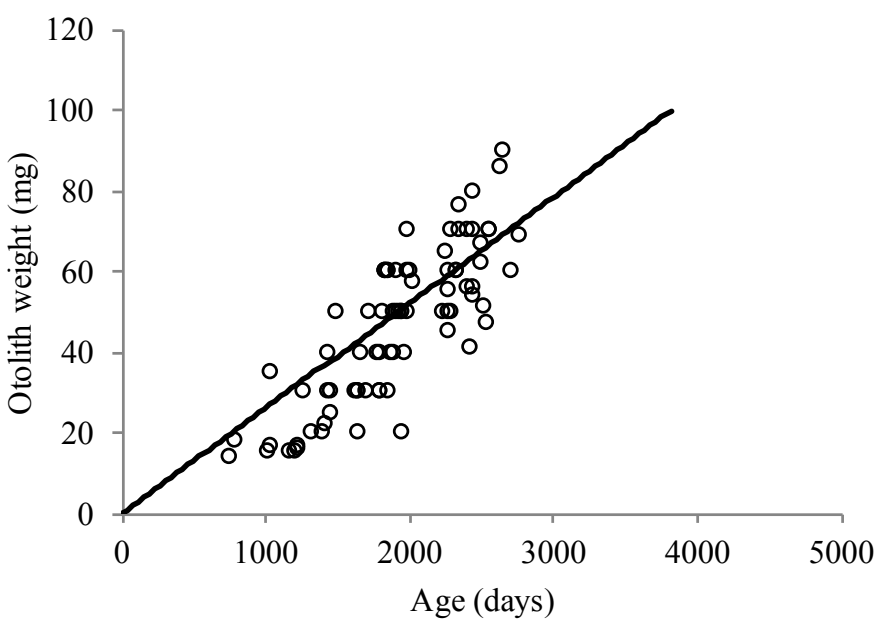

Figure 3. Otolith weight (mg) as a function of age in days in Trachurus murphyi. $\mathrm{OW}=$ otolith weight $(\mathrm{mg}) ; \mathrm{t}=$ age (days); $\mathrm{OW}=$ $0.0323^{*} \mathrm{t}-15.197\left(r^{2}=0.68\right)$. / Peso del otolito $(\mathrm{mg})$ como una función de la edad en días en Trachurus murphyi. $\mathrm{OW}=$ peso del otolito (mg); $\mathrm{t}=$ edad (días); $\mathrm{OW}=0,0323 * t-15,197\left(r^{2}=0,68\right)$.

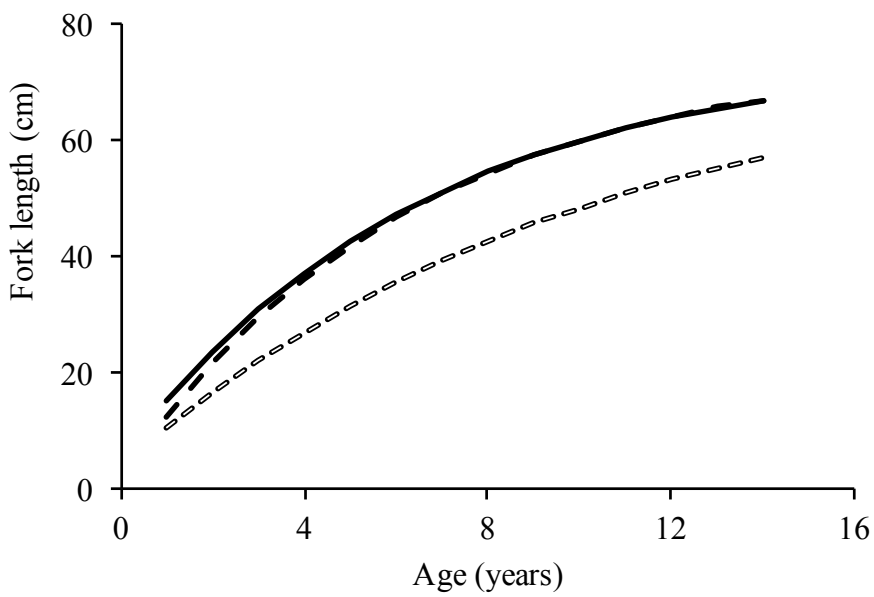

FIGURE 4. von Bertalanffy growth curves of Trachurus murphyi fit with the parameter estimations of the three methods used in this study. Solid line: otolith weight; dashed line: daily increments; dashed hollow line: annual rings. / Curvas de crecimiento de von Bertalanffy de Trachurus murphyi ajustadas con los parámetros estimados mediante los tres métodos utilizados en este estudio. Línea continua: peso del otolito; línea discontinua: incrementos diarios; línea hueca discontinua: anillos anuales. 
TABLE 1. Individual growth parameters of the von Bertalanffy equation in Trachurus murphyi using three methods: daily increments, annual rings and otolith weight. / Parámetros de crecimiento individual de la ecuación de von Bertalanffy en Trachurus murphyi utilizando tres métodos: incrementos diarios, anillos anuales y peso del otolito.

\begin{tabular}{|c|c|c|c|c|c|c|c|c|}
\hline Method & $r^{2}$ & Parameters & value & $\begin{array}{l}\text { Standard } \\
\text { Error }\end{array}$ & $\begin{array}{c}t \\
\text { value }\end{array}$ & $\begin{array}{c}95 \% \\
\text { Confidence }\end{array}$ & Limits & $\begin{array}{c}\mathrm{p} \\
\text { Value }\end{array}$ \\
\hline \multirow{3}{*}{$\begin{array}{l}\text { Daily } \\
\text { Increments }\end{array}$} & \multirow{3}{*}{0.78} & $\mathrm{FL}_{\infty}(\mathrm{cm})$ & 75.0 & & & & & \\
\hline & & $\mathrm{K}\left(\right.$ year $\left.^{-1}\right)$ & 0.16 & 0.04 & 4.26 & 0.09 & 0.23 & 0.00 \\
\hline & & $t_{0}$ (years) & -0.13 & 0.17 & -2.73 & -0.47 & 0.22 & 0.01 \\
\hline \multirow{3}{*}{$\begin{array}{l}\text { Annual } \\
\text { Rings }\end{array}$} & \multirow{3}{*}{0.80} & $\mathrm{FL}_{\infty}(\mathrm{cm})$ & 74.7 & 1.6 & 47.8 & 71.6 & 77.1 & 0.00 \\
\hline & & $\mathrm{K}\left(\right.$ year $\left.^{-1}\right)$ & 0.1 & 0.0 & 22.9 & 0.1 & 0.1 & 0.00 \\
\hline & & $\mathrm{t}_{0}$ (years) & -0.5 & 0.1 & -5.4 & -0.7 & -0.3 & 0.00 \\
\hline \multirow{3}{*}{$\begin{array}{l}\text { Otolith } \\
\text { Weight }\end{array}$} & \multirow{3}{*}{0.98} & $\mathrm{FL}_{\infty}(\mathrm{cm})$ & 75.0 & 5.3 & 14.2 & 64.5 & 85.5 & 0.00 \\
\hline & & $\mathrm{K}\left(\right.$ year $\left.^{-1}\right)$ & 0.15 & 0.03 & 6.12 & 0.10 & 0.20 & 0.00 \\
\hline & & $t_{0}$ (years) & -0.48 & 0.25 & -1.96 & -0.97 & 0.01 & 0.05 \\
\hline
\end{tabular}

TABLE 2. Curve comparison test of von Bertalanffy growth curves using analysis of residuals of sum of squares. D.F.= degrees of freedom. / Test para la comparación de curvas de crecimiento de von Bertalanffy utilizando análisis de residuos de suma de cuadrados. D.F. = grados de libertad.

\begin{tabular}{lrrc}
\hline Sum of squares & 162263 & 521642 & Annual rings \\
D. F. & 7607 & 7682 & vs. \\
F estimated & 225 & 1.35 & Otolith weight \\
& & & \\
Sum of squares & 162263 & 542627 & Annual rings \\
D. F. & 7607 & 7816 & vs. \\
F estimated & 85 & 1.17 & Daily increments \\
& & & Daily increments \\
Sum of squares & 6905 & 7697 & vs. \\
D. F. & 185 & 281 & Otolith weight \\
F estimated & 0.22 & 1.26 & \\
\hline
\end{tabular}

\section{DISCUSSION}

The methods used to determine the age of adult individuals of T. murphyi have been annual ring counts in entire otoliths, annual ring counts in transverse sections of otoliths (Pavez \& Saa 1978; Aguayo et al. 1981; Kochkin 1998) and the analysis of modal progression (Cubillos \& Grechina 1998). However, the growth parameters of the von Bertalanffy equation reported have varied widely both for T. murphyi and for other species of the genus Trachurus (Waldrom \& Kerstan 2001; Araya et al. 2003; Yankova et al. 2010; Yankova 2013). This may be due to the choice and use of criteria to interpret the annual rings, i.e. what is understood by an annual ring and how it is identified in otoliths. Waldron \& Kerstan (2001) indicated that the otoliths of the genus Trachurus are very difficult to interpret, since they have zones of annual growth with not only a translucent and opaque area, but it may contain two or more translucent zones or false rings. These appear similar to annual rings, and thus may be erroneously interpreted as "years of life", leading to overestimation of individual age. For example, Kochkin (1998) worked with annual rings and reported that $\mathrm{K}=0.11$ year $^{-1}$ for $T$. murphyi, which is close similar to $\mathrm{K}=0.10$ year $^{-1}$ estimated in the present study with the same technique. 
TABLE 3. Frequency distribution of lengths at different ages in Trachurus murphyi $(n=1300)$. Nomenclature: $F L=$ fork length (cm). / Distribución de frecuencias de longitudes a diferentes edades en Trachurus murphyi $(n=1300)$. Nomenclatura: $F L=$ longitud de la horquilla (cm).

\begin{tabular}{|c|c|c|c|c|c|c|c|c|c|c|c|c|}
\hline \multicolumn{13}{|c|}{ AGE (years) } \\
\hline $\mathrm{FL}(\mathrm{cm})$ & 1 & 2 & 3 & 4 & 5 & 6 & 7 & 8 & 9 & 10 & 11 & Total \\
\hline 19 & 1 & & & & & & & & & & & 1 \\
\hline 20 & 2 & & & & & & & & & & & 2 \\
\hline 21 & 16 & & & & & & & & & & & 16 \\
\hline 22 & 40 & & & & & & & & & & & 40 \\
\hline 23 & 21 & 4 & & & & & & & & & & 25 \\
\hline 24 & 4 & 2 & & & & & & & & & & 6 \\
\hline 25 & 8 & 20 & 1 & & & & & & & & & 29 \\
\hline 26 & 5 & 27 & 1 & & & & & & & & & 33 \\
\hline 27 & & 30 & 6 & & & & & & & & & 36 \\
\hline 28 & & 42 & 18 & & & & & & & & & 60 \\
\hline 29 & & 29 & 52 & 3 & & & & & & & & 84 \\
\hline 30 & & 35 & 47 & 7 & & & & & & & & 89 \\
\hline 31 & & 13 & 25 & 3 & & & & & & & & 41 \\
\hline 32 & & 9 & 76 & & & & & & & & & 85 \\
\hline 33 & & 1 & 72 & 11 & 1 & & & & & & & 85 \\
\hline 34 & & & 35 & 14 & 2 & & & & & & & 51 \\
\hline 35 & & & 20 & 18 & 2 & & & & & & & 40 \\
\hline 36 & & & 14 & 15 & 4 & & & & & & & 33 \\
\hline 37 & & & 3 & 25 & 5 & & & & & & & 33 \\
\hline 38 & & & 4 & 24 & 9 & 1 & & & & & & 38 \\
\hline 39 & & & 3 & 23 & 15 & 3 & & & & & & 44 \\
\hline 40 & & & & 12 & 17 & 1 & & & & & & 30 \\
\hline 41 & & & & 11 & 17 & 2 & 1 & & & & & 31 \\
\hline 42 & & & & 13 & 13 & 9 & 2 & & & & & 37 \\
\hline 43 & & & & 5 & 13 & 2 & 5 & & & & & 25 \\
\hline 44 & & & & 1 & 15 & 18 & 2 & & & & & 36 \\
\hline 45 & & & & 1 & 12 & 11 & 2 & & & & & 26 \\
\hline 46 & & & & & 9 & 14 & 8 & & & & & 31 \\
\hline 47 & & & & & 7 & 15 & 5 & & & & & 27 \\
\hline 48 & & & & & 5 & 17 & 12 & 6 & & & & 40 \\
\hline 49 & & & & & 5 & 6 & 7 & 4 & & & & 22 \\
\hline 50 & & & & & 3 & 11 & 15 & 3 & 2 & & & 34 \\
\hline 51 & & & & & 1 & 3 & 7 & 4 & 1 & & & 16 \\
\hline 52 & & & & & & 3 & 6 & 2 & 2 & & & 13 \\
\hline 53 & & & & & & 4 & 1 & 5 & & 1 & & 11 \\
\hline 54 & & & & & & & 3 & 2 & & & & 5 \\
\hline 55 & & & & & & & 8 & 9 & & & & 17 \\
\hline 56 & & & & & & & 3 & 5 & 3 & 2 & & 13 \\
\hline 57 & & & & & & & & 1 & & 1 & & 2 \\
\hline 58 & & & & & & & & 2 & & & & 2 \\
\hline 59 & & & & & & & & 1 & & & & 1 \\
\hline 60 & & & & & & & & & 1 & 2 & & 3 \\
\hline 61 & & & & & & & & & 1 & & & 1 \\
\hline 62 & & & & & & & & & 1 & 2 & & 3 \\
\hline 63 & & & & & & & & & & 2 & & 2 \\
\hline 64 & & & & & & & & & & & 1 & 1 \\
\hline $\mathrm{n}$ & 97 & 212 & 377 & 186 & 155 & 120 & 87 & 44 & 11 & 10 & 1 & 1300 \\
\hline$\%$ & 7.5 & 16.3 & 29.0 & 14.3 & 11.9 & 9.2 & 6.7 & 3.4 & 0.8 & 0.8 & 0.1 & 100 \\
\hline FL mean & 22.5 & 28.0 & 31.8 & 37.2 & 42.2 & 46.3 & 49.2 & 52.8 & 55.1 & 59.2 & 64.0 & \\
\hline SD & 13.3 & 14.3 & 25.7 & 8.0 & 5.6 & 6.0 & 4.0 & 2.3 & 0.8 & 0.5 & 0.0 & \\
\hline
\end{tabular}


However, Dioses (2013) estimated $K=0.155$ year $^{-1}$ for T. murphyi off Peru by using annual rings, which is similar to both $\mathrm{K}=0.16$ year $^{-1}$ estimated in the present study with daily ring counts, and $\mathrm{K}=0.155$ year $^{-1}$ with the technique of otolith weight.

Otolith weight has been used to estimate fish age in hoki Macruronus magellanicus (Pino et al., 2004), leopard coral trout Plectroponus leopardus (Lou et al. 2005), sky emperor Lethrinus mahsena (Pilling et al. 2003) and cod Gadus morhua (Bermejo 2014) among other fish species. We recommend using otolith weight to estimate age in T. murphyi (Fig. 4) due to this method is statistically reliable, but also cheap and fast.

\section{ACKNOWLEDGEMENTS}

HA thanks the Instituto de Investigación Pesquera (INPESCA) for facilitating the otoliths used in this study. LC thanks to the Asociación de Industriales Pesqueros (ASIPES) de Concepción, Chile, due to an annual scholarship to carry out the Doctorado en Ciencias con mención en Manejo de Recursos Acuáticos Renovables (Doctorado MaReA) at the Universidad de Concepción.

\section{REFERENCES}

Aguayo, M., Estay, E., Ojeda, V. 1981. Determinación de edad y crecimiento de jurel (Trachurus murphyi) en las zonas de Arica-Coquimbo y Talcahuano. Informe Subsecretaría de Pesca. Instituto de Fomento Pesquero (IFOP), Chile. 88pp.

Araya, M., Cubillos, L.A., Guzmán, M., Peñailillo, J., Sepúlveda, A. 2001. Evidence of a relationship between age and otolith weight in the Chilean Jack mackerel, Trachurus symmetricus murphyi (Nichols). Fisheries Research 51: 1726. https://doi.org/10.1016/S0165-7836(00)00233-2

Araya, M., Medina, M., Arancibia, H. 2003. Preliminary results of the empirical validation of daily increments in otoliths of Jack mackerel Trachurus symmetricus (Ayres, 1855) marked with oxytetracycline. Scientia Marina 67(4): 471475. https://doi.org/10.3989/scimar.2003.67n4471

Bermejo, S. 2014. The benefits of using otolith weight in statistical fish age clasification: A case study of Atlantic cod species. Computers and Electronics in Agriculture 107:1-7. https://doi.org/10.1016/j.compag.2014.06.001

Cisterna, L., Arancibia, H. 2017. Estimation of the age of jack mackerel (Trachurus murphyi) using growth rings in sagittae otoliths. Gayana 81(1): 28-31. http://doi.org/10.4067/ S0717-65382017000100028
Cubillos L., Grechina, A. 1998. Crecimiento del jurel Trachurus symmetricus murphyi (Nichols) del Pacífico Suroriental mediante análisis de progresión modal. In: Arcos, D. (Eds) Biología y ecología del jurel en aguas chilenas: 151-161. Instituto de Investigación Pesquera, Talcahuano, Chile.

Dioses, T. 2013. Edad y crecimiento de jurel Trachurus murphyi en el Perú. En: Csirke, R., Guevara-Carrasco, R., Espino, M. (Eds) Ecología, pesquería y conservación del jurel (Trachurus murphyi) en el Perú. Revista Peruana de Biología 20(1): 45-52.

Green, B.S., Mapstone, B.D., Carlos, G., Begg, G.A. (Eds) 2009. Tropical Fish Otoliths: Information for Assessment, Management and Ecology. First edition. Springer. 326 pp.

Haddom, M. 2001. Modelling and quantitative methods in fisheries. Chapman and Hall, Boca Raton, USA. 424 pp.

Hanson, D., Satanfford, C. 2017. Modeling Otolith Weight using Fish Age and Length: Applications to Age Determination. Transactions of the American Fisheries Society, 146: 778790. https://doi.org/ 10.1080/00028487.2017.1310138

Kochkin, P. 1998. Edad y crecimiento del jurel (Trachurus symmetricus murphyi (Nichols)) en aguas oceánicas del Pacífico sur. In: Arcos, D (Ed) Biología y ecología del jurel en aguas chilenas: 163-172. Instituto de Investigación Pesquera, Talcahuano, Chile.

Lou, D., Mapstone, B., Russ, G., Davies, C., Begg, G. 2005. Using otolith weight-age relationships to predict age-based metrics of coral reef fish population at different spatial scales. Fisheries Research 71: 279-294. https://doi. org/10.1016/j.fishres.2004.09.003

Pannella, G. 1974. Otolith growth patterns: An aid in age determination in temperate and tropical fishes. In: Bagenal, T.B. (Ed) The proceeding of an International Symposium on ageing of fish: 28-39. Unwin Brothers, Surrey Engl.

Pavez, P., Saa, E. 1978. Determinación de edad y crecimiento del jurel Trachurus murphyi Nichols, 1920. Investigaciones Marinas 6(6): 89-100.

Pilling, G., Grandcourt, E., Kirkwood, G. 2003. The utility of otolith weight as a predictor of age in the emperor Lethrinus mahsena and other tropical fish species. Fisheries Research 60: 493-506. https://doi.org/10.1016/S01657836(02)00087-5

Pino, C., Cubillos, L., Araya, M., Sepúlveda, A. 2004. Otolith weight as an estimator of age in the Patagonian grenadier, Macruronus magellanicus, in central-south Chile. Fisheries Research 66: 145-156. https://doi.org/10.1016/j. fishres.2003.07.003

Ralston, S., Williams, H. 1989. Numerical integration of daily growth increments: an efficient means of ageing tropical fishes for stock assessment. Fishery Bulletin 87(1): 1-16. 
SPRFMO. 2017. Scientific Committee Report. In: 5th Scientific Committee Meeting. South Pacific Regional Fisheries Management Organization, Shanghai, China. September 23-28, 2017.

Stewart, J., Ferrell, D. 2001. Age, growth and commercial landings of yellow tail scad (Trachurus novaezelandiae) and blue mackerel (Scomber australasicus) off the coast of New South Wales, Australia. New Zealand Journal of Marine and Freshwater Research 35: 541-551. https://doi.org/10 .1080/00288330.2001.9517021.

Vasconcelos, J., Alvez, A., Gouveia, E., Faria, G. 2006. Age and growth of the blue jack mackerel, Trachurus picturatus Bowdich, 1825 (Pisces: Teleostei) off Madeira Archipelago. Life and Marine Sciences 23(A): 47-57.
Waldron, M., Kerstan, M. 2001. Age validation in horse mackerel (Trachurus trachurus) otoliths. ICES Journal of Marine Science 58: 806-813. https://doi.org/10.1006/ jmsc.2001.1071

Yankova, M., Raykov, V., Gerdzhikov, D., Frateva, P. 2010. Growth and length-weight relationships of the horse mackerel, Trachurus mediterraneus ponticus (Aleev, 1956), off the Bulgarian Black Sea coast. Turkish Journal of Zoology 34: 85-92. https://doi.org/10.3906/zoo-0811-10.

Yankova, M. 2013. A study on the growth of horse mackerel (Trachurus mediterraneus Aleev, 1956) from Bulgarian waters of the black sea using length frequency analysis. Journal of Black Sea/Mediterranean Environment 19(1): 111-120. https://doi.org/10.1155/2013/127287.

Received: 09.05.2021

Accepted: 14.06.2021 